\title{
New records of woodlice in the south of western Siberia, Russia (Isopoda: Oniscidea)
}

\author{
D.D. Khisametdinova ${ }^{1}$, P.S. Nefediev², I.H. Tuf ${ }^{3}$ \\ ${ }^{1}$ Palace of Creativity of Children and Youth, Bolshaya Sadovaya Street, 55, Rostov-on-Don 344002 \\ Russia.E-mail: dilalex@mail.ru \\ ${ }^{2}$ Altai State University, Lenina Avenue, 61, Barnaul 656049 Russia.E-mail: p.nefediev@mail.ru \\ ${ }^{3}$ Palacký University, Šlechtiteli̊27,CZ-77900 Olomouc, Czech Republic.E-mail: ivan.tuf@upol.cz
}

ABSTRACT. Three families, genera and species of terrestrial isopods are new to Asian Russia's list: Trachelipodidae, Trachelipus Budde-Lund, 1908, and Trachelipus rathkii (Brandt, 1833); Cylisticidae, Cylisticus Schnitzler, 1853, and Cylisticus convexus (De Geer, 1778); and Trichoniscidae, Trichoniscus Brandt, 1833, and Trichoniscus pygmaeus Sars, 1898. All woodlice in the south of western Siberia seem to be entirely associated with synanthropic habitats. Distributional and ecological remarks are provided for all of those anthropochore species in the study area.

How to cite this article: Khisametdinova D.D., Nefediev P.S., Tuf I.H. 2016. New records of woodlice in the south of western Siberia, Russia (Isopoda: Oniscidea) // Invert. Zool. Vol.13. No.1. P.51-55. doi: 10.15298/invertzool.13.1.04

KEY WORDS: terrestrial isopods, Trachelipus rathkii, Cylisticus convexus, Trichoniscus pygmaeus, anthropochore, faunistics, introduction, Siberia.

\section{Новые находки мокриц на юге Западной Сибири (Россия) (Isopoda: Oniscidea)}

\section{Д.Д. Хисаметдинова', П.С. Нефедьев², И.Х. Туфр}

\author{
${ }^{1}$ Двореи творчества детей и молодежи, ул. Большая Садовая, 55, Ростов-на-Дону 344002 \\ Poccuя.E-mail:dilalex@mail.ru \\ ${ }^{2}$ Алтайский государственный университет, проспект Ленина, 61, Барнаул 656049 Россия. \\ E-mail:p.nefediev@mail.ru \\ ${ }^{3}$ Университет им. Палачкого, Оломоуи, Чехия. E-mail: ivan.tuf@upol.cz
}

РЕЗЮМЕ. Три семейства, рода и вида наземных изопод оказались новыми для азиатской России: Trachelipodidae, Trachelipus Budde-Lund, 1908, и Trachelipus rathkii (Brandt, 1833); Cylisticidae, Cylisticus Schnitzler, 1853, и Cylisticus convexus (De Geer, 1778); и Trichoniscidae, Trichoniscus Brandt, 1833, и Trichoniscus pygmaeus Sars, 1898. Все мокрицы на юге Западной Сибири, по всей видимости, полностью связаны с синантропными биотопами. Для всех этих антропохорных видов исследуемого региона приведены замечания по распространению и экологии.

Как цитировать эту статью: Khisametdinova D.D., Nefediev P.S., Tuf I.H. 2016. New records of woodlice in the south of western Siberia, Russia (Isopoda: Oniscidea) // Invert. Zool. Vol.13. No.1. P.51-55. doi: 10.15298/invertzool.13.1.04

КЛЮЧЕВЫЕ СЛОВА: наземные изоподы, Trachelipus rathkii, Cylisticus convexus, Trichoniscus pygmaeus, антропохор, фаунистика, интродуцент, Сибирь. 


\section{Introduction}

The Siberian fauna of terrestrial isopods is very poorly-studied. Only two introduced woodlouse species have hitherto been reported in Siberia, Russia (Kuznetsova, Gongalsky, 2012). Both records are contained in unpublished archives (Daria Kuznetsova, pers. comm.). The first concerns Porcellionides pruinosus Brandt, 1833 (Porcellionidae), in eastern Siberia, a ubiquitous species presumably Mediterranean in origin, the underlying material being housed in the Zoological Institute of the Russian Academy of Sciences (ZIN RAS) and marked in Russian in the archive book as "Record No.1/1778, ZIN RAS, collected by Czekanowski, determined by Budde-Lund, Baikal, 1883”. In all probability this material was collected by Aleksander Lavrentievitch Czekanowski at the time of his exile to Siberia from 1865 to 1876 . The second record concerns Porcellio laevis Latreille, 1804 (Porcellionidae), the underlying material being housed in the Zoological Museum of the Lomonosov Moscow State University and taken on an undefined date by an unknown collector in the Barnaul Uyezd (= Barnaul County). In all probability, the latter material was taken between 1897 to 1917 when the Barnaul Uyezd was an administrative subdivision of the Tomsk Guberniya (= Tomsk Governorate), western Siberia.

The samples treated below have been deposited in the collection of the Altai State University, Barnaul, Russia (ASU).

\section{Taxonomic part}

\section{Order ONISCIDEA}

\section{Family TRACHELIPODIDAE}

\section{Trachelipus rathkii (Brandt, 1833)}

MATERIAL EXAMINED. $2 \sigma^{7} \sigma^{7}, 6$ q (including $1+$ with marsupium) (ASU), Russia, southwestern Siberia, Altai Province, Barnaul, "Izumrudnyi" Park, Acer and Populus, 6.06. 2014; $6 \bigcirc^{7} \bigcirc^{7}, 1$ ( 1 (with marsupium) (ASU),
Russia, Altai Prov., Barnaul, "Nagornyi” Park, Pinus sibirica, Abies sibirica, Acer, 19.06.2014; 1 † (ASU), Russia, Altai Prov., Barnaul, "Yubileinyi" Park, July 2014, soil sampling (10-20 cm), all leg. A.A. Streltsova; $8 \sigma^{7} \sigma^{7}, 7$ $\bigcirc+5$ juv. (ASU), Russia, Altai Prov., Barnaul, "Lesnaya Skazka" Park, Acer and Betula, under planks, stones, in litter, 1.05.2015; $8 \sigma^{7} \sigma^{7}, 6$ 우 (ASU), Russia, Altai Prov., Pervomaiskii Distr., Beryozki Railway Station, open hand-made grounds, 11.05.2015; $1 \mathrm{O}^{\top}, 20$ 우 (including 19 우 with marsupia) (ASU), Russia, Altai Prov., Barnaul, M.A. Lisavenko Research Institute for Horticulture of Siberia, summer hothouse, 16.06.2015; 1 (with marsupium) (ASU), same locality, heated hothouse, 16.06.2015; $3 \mathrm{O}^{\top} \mathrm{O}^{\top}$, 14 우 (including 10 우 with marsupia) (ASU), same locality, open hand-made grounds, 16.06.2015, all leg. P.S. Nefediev.

DISTRIBUTION. Being European in origin, T. rathkii, due to the association with man, has become widespread throughout most of Europe (except the Mediterranean territories), inhabiting Norway, Sweden, Denmark, Finland, Estonia, Latvia, Lithuania, Great Britain including the Channel Islands, Iceland, the Netherlands, Belgium, France, Germany, Austria, Hungary, Czech Republic, Slovakia, Switzerland, Italy, Spain, Romania, Moldova, former Yugoslavia including Slovenia, Serbia and Macedonia, Bulgaria, Poland, Belarus, Ukraine, Abkhazia, Georgia, Azerbaijan, northwestern European Russia (the Leningrad, Belgorod, Kursk, Tver, Kaluga, Moscow, Penza, Saratov and Tula areas, the Mari El Republic and the Republic of Mordovia) and southern European Russia (the Rostov-on-Don Area and the Republic of Crimea); also introduced to the Americas (Canada, USA and Brazil) (Vandel, 1962; Karaman, 1966; Harding, Sutton, 1985; Leistikow, Wägele, 1999; Schmalfuss, 2003; Khisametdinova, 2011; Kuznetsova, Gongalsky, 2012; Boxshall, 2013).

REMARKS. The basically European genus Trachelipus Budde-Lund, 1908, and the widespread species T. rathkii (Brandt, 1833), as well as the family Trachelipodidae they belong to, are formally new to the isopod fauna of the Asian part of Russia. In Asian Russia, T. rathkii 
dwells in anthropogenic and semi-natural habitats such as hothouses and city parks in the city of Barnaul and on open private grounds in the Pervomaiskii District, all within the Altai Province. At the same time, Khisametdinova (2009) refers this species to a group of misanthropes which cannot stand human neighbourhood. It seems to be the most widespread and abundant terrestrial woodlouse in southwestern Siberia.

Contrary to Khisametdinova's (2009) records from European Russia, this species is frequently sampled in cities in Central and Northern Europe. Trachelipus rathkii is common in Vilnius, Lithuania (Vilisics et al., 2012), in Helsinki, Finland (Vilisics, Terhivuo, 2009) or in Olomouc, Czech Republic (Riedel et al., 2009). At the northern periphery of its distribution in central Finland, this species occurs exclusively in anthropogenic habitats (Vilisics, Terhivuo, 2009). Also its occurrences in North America are associated with human settlements (e.g. Hornung et al., 2015). The highest surface activity is controlled by high temperature and high humidity. In cold and/or dry months, $T$. rathkii inhabits deeper soil layers and shelters. Trachelipus rathkii is a typical alien species as demonstrated by its populations found in plantations of non-native trees (Farkas et al., 2013) and its indiscriminative feeding on native as well as non-native leaf litter (Gerlach et al., 2014). Another typical character of such an expansive species lies in its high fecundity and the capability of females for storing sperm and utilizing its stock in repeated brood production (Suzuki, Ziegler, 2005).

\section{Family CYLISTICIDAE}

\section{Cylisticus convexus (De Geer, 1778)}

MATERIAL EXAMINED. $1 \sigma^{\gamma}, 1$ (with marsupium), 1 juv. (ASU), Russia, southwestern Siberia, Altai Province, Barnaul, M.A. Lisavenko Research Institute for Horticulture of Siberia, heated hothouse, 16.06.2015, leg. P.S. Nefediev.

DISTRIBUTION. Throughout Europe and Asia Minor, in Great Britain including Northern Ireland, Ireland, the Netherlands, Belgium,
France, Germany, Switzerland, Austria, Hungary, Czech Republic, Slovakia, former Yugoslavia including Bosnia and Herzegovina, Croatia, Serbia, Montenegro and Slovenia, Albania, mainland Italy together with Corsica, Greece including the Dodecanese Islands, Spain including the Balearic Islands, Romania, Bulgaria, Poland, Ukraine, Latvia, Lithuania, Estonia, Finland, Sweden, Norway, Denmark, Turkey, central and northeastern European Russia (the Kaluga, Moscow and Chelyabinsk areas), southern European Russia (the Rostov-on-Don and Voronezh areas and the Republic of Crimea); also introduced to northern Africa, as far as St. Helena Island in the Atlantic, the Americas (Canada, USA, Mexico and Argentina), also Australia (Vandel, 1962; Karaman, 1966; Leistikow, Wägele, 1999; Schmalfuss, 2003; Khisametdinova, 2011; Kuznetsova, Gongalsky, 2012; Boxshall, 2013).

REMARKS. At present, $C$. convexus has also been found introduced to a hothouse of the M.A. Lisavenko Research Institute for Horticulture of Siberia, Barnaul, Altai Province. Both the genus Cylisticus Schnitzler, 1853, and the species C. convexus (De Geer, 1778), as well as the family Cylisticidae they belong to, are recorded in the Asian part of Russia for the first time. According to the accepted classification of synanthrope woodlice (Khisametdinova, 2009), C. convexus, being a fully synanthropic species, has partly lost its capability for existing beyond anthropogenic habitats. Such a distribution pattern is similar in Europe as well, where this species has only been found synanthropic in Finland (Vilisics, Terhivuo, 2009), as well as in Ireland (Cawley, 1996). Its distribution in North America shows the same pattern as described for T. rathkii (Hornung et al., 2015). In addition, $C$. convexus females are capable for storing and repeatedlyutilizing sperm(Suzuki,Ziegler, 2005).

\section{Family TRICHONISCIDAE}

\section{Trichoniscus pygmaeus Sars, 1898}

MATERIAL EXAMINED. $1 \sigma^{\top}, 3$ o (including 2 ㅇ with marsupia) (ASU), Russia, 
southwestern Siberia, Altai Province, Barnaul, South Siberian Botanical Garden, fern greenhouse, 19.06.12.2013, leg. P.S. Nefediev.

DISTRIBUTION. Mainly Europe: Austria, Belgium, Czech Republic, Denmark, Estonia, Finland, France together with Corsica, Germany, Ireland, Great Britain including the Isle of Wight and Northern Ireland, Italy including Sicily, Malta, the Netherlands, Norway, Poland, Romania, Slovakia, Spain together with the Balearic Islands, Portugal (the Azores only), Sweden, Switzerland, Moldova, Ukraine, southern European Russia (Krasnodar Province); also distributed in northern Africa (Morocco) and introduced to North America (Canada, USA) (Vandel, 1960; Leistikow, Wägele, 1999; Schmalfuss, 2003; Kuznetsova, Gongalsky, 2012; Boxshall, 2013).

REMARKS. The genus Trichoniscus Brandt, 1833 and the species T.pygmaeus Sars, 1898, in southwestern Siberia, as well as the family Trichoniscidae they belong to, are new to the isopod fauna of the Asian part of Russia. In the northern part of its distribution range, T. pygmae$u s$ is abundant in a wide variety of both natural and synanthropic habitats (Cawley, 1996).

\section{Conclusions}

To date, at least four species of woodlice are known to occur in the south of western Siberia, Russia, namely, Porcellio laevis Latreille, 1804, Trachelipus rathkii (Brandt, 1833), Cylisticus convexus (De Geer, 1778) and Trichoniscus pygmaeus Sars, 1898. The latter three species, together with their genera (Trachelipus BuddeLund, 1908, Cylisticus Schnitzler, 1853, Trichoniscus Brandt, 1833) and families (Trachelipodidae, Cylisticidae, Trichoniscidae) they belong to, are new to the Asian part of Russia. All present findings of terrestrial isopods are entirely associated with synanthropic habitats (glasshouses and botanical gardens, city parks and open hand-made grounds), suggesting that their occurrences there are not natural. Nevertheless, T. rathkii lives also outdoors and thus seems to be well adapted to the continental and rather harsh climate of southwestern Siberia.
The presence in western Siberia of still another few species is plausible. Thus, $P$. pruinosus has already been recorded in eastern Siberia. The distribution of this species is known to be associated with human settlements, dung heaps in particular, as compost material maintains warmth also during winters (e.g. Cawley, 1996). Another very plausible candidate species is Hyloniscus riparius (C. Koch, 1838) (Trichoniscidae). This species has recently been found near the city of Moscow in high densities (Gongalsky, Kuznetsova, 2010), as well as in Lithuania (Tuf et al., 2014) and Canada (McApline, Oldham, 2011). Its capability for expanding in new areas is well-known (Schultz, 1965). So systematic searches for woodlice in Siberia in the future seem to be quite promising in terms of further species records.

ACKNOWLEDGEMENTS. We are most grateful to S.I. Golovatch (Moscow, Russia) who kindly edited the English of an advanced draft. We are very much obliged to D.M. Kuznetsova (Moscow, Russia) for the valuable information on dubious records. We are also thankful to Alexander Shmakov (Barnaul, Russia), Director of the South Siberian Botanical Garden, and to Vladimir Usenko (Barnaul, Russia), Director of the M.A. Lisavenko Research Institute for Horticulture of Siberia, who allowed us to collect material inside and outside hothouses of their institutions. Our deepest gratitude extends to A.A. Streltsova (Barnaul, Russia) who donated us her material for the present study.

\section{References}

Boxshall G. 2013. Fauna Europaea: Isopoda, Oniscidea // Fauna Europaea, version 2.6. Available online at http://www.fauna-eu.org (accessed 15 February 2016).

Cawley M. 1996. The woodlice (Crustacea, Isopoda) of Cos Sligo and Leitrim // The Irish Naturalists' Journal. Vol.25. No.8. P.273-277.

Farkas S., Vilisics F., Balint L., Bóka B., Juhász N., Otártics M., Szabó E., Szijártó Zs., Üst N. 2013. Isopod communities of Black locust (Robinia pseudoacacia L.) plantations in Transdanubia (Hungary) // Natura Somogyiensis. Vol.23. P.125-134.

Gerlach A., Russell D.J., Jaeschke B., Römbke J. 2014. Feeding preferences of native terrestrial isopod species (Oniscoidea, Isopoda) for native and introduced leaf litter // Applied Soil Ecology. Vol.83. P.95-100. 
Gongalsky K.B., Kuznetsova D.M. 2010. [Additions to the woodlouse fauna (Isopoda: Oniscidea) of the Moscow Region] // Byulleten' Moskovskogo obshchestva ispytatelei prirody, otdel biologicheskii. Vol.115. No.3. P.46-47 [in Russian].

Harding P., Sutton S. 1985. Woodlice in Britain and Ireland: Distribution and habitat. Huntingdon: Institute of Terrestrial Ecology. 151 p.

Hornung E., Szlavecz K., Dombos M. 2015. Demography of some non-native isopods (Crustacea, Isopoda, Oniscidea) in a Mid-Atlantic forest, USA // ZooKeys. Vol.515. P.127-143.

Leistikow A., Wägele J.W. 1999. Checklist of the terrestrial isopods of the New World (Crustacea, Isopoda, Oniscidea) // Revista Brasileira de Zoologia. Vol.16. No.1. P.1-72.

Karaman M. 1966. Kopnezi izopodi (Isopoda terrestria) Jugoslavije// Zbornik filozofskog Fakulteta u Prištini. Vol.3. P.371-404.

Khisametdinova D.D. 2009. [Eco-faunistic characteristics of woodlice (Isopoda, Oniscidea) of the Lower Don River]. PhD Thesis. Southern Federal University, Rostov-on-Don. 196 p. [in Russian].

Khisametdinova D.D. 2011. Terrestrial isopods (Isopoda, Oniscidea) of the Rostov Region, SW Russia // Zidar P., Štrus J. (eds). Proceedings of the $8^{\text {th }}$ International Symposium of Terrestrial Isopod Biology - ISTIB 2011, June 19-23, 2011, Hotel Ribno, Bled, Slovenia. University of Ljubljana, Biotechnical Faculty, Department of Biology, Ljubljana. P.111-112.

Kuznetsova D.M., Gongalsky K.B. 2012. Cartographic analysis of woodlice fauna of the former USSR // Strus J., Taiti S., Sfenthourakis S. (eds). Advances in Terrestrial Isopod Biology. ZooKeys. No.176. P.1-11.

McApline D.F., Oldham M.J. 2011. Occurrence of the woodlouse, Hyloniscus riparius (Koch) (Isopoda: Trichoniscidae), in Ontario // Journal of the Entomological Society of Ontario. Vol.142. P.49-52.
Riedel P., Navrátil M., Tuf I.H., Tufová J. 2009. Terrestrial isopods (Isopoda: Oniscidea) and millipedes (Diplopoda) of the city of Olomouc // Tajovský K., Schlaghamerský J., Pižl V. (eds.). Contributions to Soil Zoology in Central Europe III. Institute of Soil Biology, Biology Centre, ASCR, České Budějovice. P.125-132.

Schmalfuss H. 2003. World catalog of terrestrial isopods (Isopoda: Oniscidea) // Stuttgarter Beiträge zur Naturkunde, Serie A. Nr.654. 341 p.

Schmalfuss H., Wolf-Schwenninger K. 2002. A bibliography of terrestrial isopods (Crustacea, Isopoda, Oniscidea) // Stuttgarter Beiträge zur Naturkunde, Serie A. Nr.639. 120 p.

Schultz G.A. 1965. The distribution and general biology of Hyloniscus riparius (Koch) (Isopoda, Oniscoidea) in North America // Crustaceana. Vol.8. P.131-140.

Suzuki S., Ziegler A. 2005. Structural investigation of the female genitalia and sperm-storage sites in the terrestrial isopod Armadillidium vulgare (Crustacea, Isopoda) // Arthropod Structure \& Development. Vol.34. P.441-454.

Tuf I.H., Ivinskis P., Rimšaitė J. 2014. Four terrestrial isopod species (Isopoda: Oniscidea) new for Lithuanian fauna and data on distribution of another seven species // New and Rare for Lithuania Insect Species. Vol.26. P.86-89.

Vandel A. 1960. Faune de France. Vol.64. Isopodes terrestres (première partie). P.1-416.

Vandel A. 1962. Faune de France. Vol.66. Isopodes terrestres (deuxième partie). P.417-931.

Vilisics F., Ivinskis P., Rimšaite J. 2012. Terrestrial isopods (Crustacea, Oniscidea) at the Baltic Sea coast in Lithuania // Zoology and Ecology. Vol.22. No.3-4. P.226-232.

Vilisics F., Terhivuo J. 2009. Inspection on materials contributing to the knowledge of terrestrial Isopoda (Crustacea, Oniscidea) in Finland // Memoranda Soc. Fauna Flora Fennica. Vol.85. P.9-15.

Responible editor K.G. Mikhailov 